\title{
Tingkat Pengetahuan, Sikap, dan Tindakan Dalam Pemanfaatan Tanaman Sebagai Obat Tradisional Oleh Masyarakat Di Desa Pringgabaya Kabupaten Lombok Timur
}

\author{
Baiq Dwigita Wahyu Izzatia ${ }^{\mathrm{a}, 1}$, Baiq Nurbaety ${ }^{\mathrm{a}, 2}$, Baiq Leny Nopitasari ${ }^{\mathrm{a}, 3}$, Agus Suprianto ${ }^{\mathrm{b}, 1}$ \\ aUniversitas Muhammadiyah Mataram, J1. KH. Ahmad Dahlan No. I, Pagesangan, Kec. Mataram, Kota Mataram, 83 I I5 \\ ${ }^{\mathrm{b}}$ RSUD Provinsi NTB, J1. Praburangkasari, Dasan Cermen, Kec. Sandubaya, Kota Mataram, 83232 \\ ${ }^{1}$ dwigitab@gmail.com; ${ }^{2}$ bq.tyee@gmail.com; ${ }^{3}$ baiqleny.nopitasari@gmail.com; ${ }^{4}$ agus.pbsa@gmail.com \\ *korespondensi penulis
}

\begin{tabular}{l}
\hline INFO ARTIKEL \\
\hline Diterima : \\
O2-I2-202I \\
Direvisi : \\
04-0I-2022 \\
Disetujui : \\
04-0I-2022 \\
\hline
\end{tabular}

\section{Kata kunci: \\ Tingkat Pengetahuan; \\ Sikap; \\ Tindakan; \\ Tanaman Obat; \\ Desa Pringgabaya.}

\section{ABSTRAK}

Masyarakat Desa Pringgabaya merupakan salah satu masyarakat di Indonesia yang masih menggunakan tanaman sebagai obat tradisional. Pengetahuan masyarakat Desa Pringgabaya tentang tanaman obat ini masih terpelihara karena merupakan tradisi secara turun temurun dari nenek moyang mereka. Pengetahuan tentang pemanfaatan tanaman obat hanya diwariskan secara lisan, sehingga kemungkinan lama kelamaan pengetahuan tersebut akan hilang atau resepnya menjadi tidak komplit. Penelitian ini bertujuan untuk mengetahui tingkat pengetahuan, sikap, dan tindakan masyarakat dalam pemanfaatan tanaman sebagai obat tradisional di Desa Pringgabaya Kabupaten Lombok Timur. Metode penelitian ini menggunakan observasional deskriptif dengan pendekatan cross sectional dengan teknik purposive sampling. Populasi dalam penelitian ini adalah masyarakat yang berusia 20 sampai 60 tahun yang bertempat tinggal di Desa Pringgabaya Kecamatan Lombok Timur yang berjumlah 7.339 orang dan didapat sampel sebanyak 379 orang. Hasil penelitian ini menunjukkan tingkat pengetahuan responden berjenis kelamin perempuan lebih banyak yaitu 193 responden (50,9\%) dibandingkan dengan laki-laki dengan jumlah 186 responden $(49,1 \%)$ dan mayoritas responden berusia $20-$ 40 tahun yaitu sebanyak 279 responden (73,6\%), variabel sikap kategori baik berjumlah 237 responden $(62,5 \%)$, dan variabel tindakan kategori baik berjumlah 154 responden $(40,0 \%)$. Simpulan penelitian ini adalah tingkat pengetahuan masyarakat tentang pemanfaatan tanaman obat termasuk kategori pengetahuan baik $(76,0 \%)$, sikap masyarakat tentang pemanfaatan tanaman obat termasuk kategori sikap baik (79,5\%), dan tindakan masyarakat tentang pemanfaatan tanaman obat termasuk kategori tindakan cukup baik (65,7\%).

\footnotetext{
Key word:

Level Of Knowledge;

Attitude;

Action

Medicinal Plants;

Pringgabaya Village.
}

\section{ABSTRACT}

Pringgabaya Village community is one of the people in Indonesia who still use medicinal plants as traditional medicine. Public knowledge about medicinal plants is still preserved because it is a tradition that has been passed down from generation to generation from the ancestors. The knowledge about the use of medicinal plants is only passed down orally, so it is possible that over time this knowledge will disappear or the recipe will not be complete. This study aims to determine the level of knowledge, attitudes, and actions of the community in the use of plants as traditional medicine in Pringgabaya Village, East Lombok Regency. This research method uses descriptive observation with a cross sectional approach with purposive sampling technique. The population in this study were people aged 20 to 60 years who lived in Pringgabaya Village, East Lombok District, amounting to 7,339 people and a sample of 379 people was obtained. The results of this study indicate that the level of knowledge of female respondents is more, namely 193 respondents (50.9\%) compared to men with a total of 186 respondents (49.1\%) and the majority of respondents aged 2040 years, as many as 279 respondents $(73.6 \%)$, the attitude variable in the good category is 237 respondents $(62.5 \%)$, and the action variable in the good 
category is I54 respondents (40.0\%). The conclusion of this study is that the level of public knowledge about the use of medicinal plants is included in the category of good knowledge $(76.0 \%)$, public attitudes about the use of medicinal plants are included in the category of good attitude (79.5\%), and community actions regarding the use of medicinal plants are included in the category of adequate action good $(65.7 \%)$.

This is an open access article under the CC-BY-SA license.

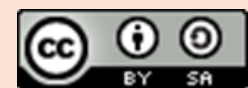

\section{Pendahuluan}

Indonesia merupakan negara kepulauan yang terletak di daerah tropis dan memiliki keanekaragaman hayati yang melimpah, kaya akan bahan baku obat, sehingga obat tradisional menjadi pilihan pengobatan yang menarik dan dapat terus dikembangkan. Lebih dari 20.000 jenis tanaman obat tumbuh dan berkembang, tetapi hanya 1.000 jenis yang tercatat dan sekitar 300 jenis telah digunakan untuk pengobatan tradisional (Arief, 2013).

Dahulu para ahli pengobatan tradisional atau dikenal dengan istilah tabib menggunakan bahan baku yang berasal dari hutan. Diperkirakan hutan Indonesia memiliki 30.000 jenis tanaman obat yang 940 jenisnya telah dinyatakan berkhasiat obat, dimana sekitar 78\% masih diperoleh melalui ekstraksi langsung dari hutan (Wahyuni, Olde, \& Sofyan, 2018).

Pengetahuan masyarakat tentang tanaman obat beserta manfaat dan kegunaannya baik untuk upaya peningkatan kesehatan, pencegahan penyakit, penyembuhan penyakit maupun pemulihan telah ada sejak zaman dahulu dan telah dimanfaatkan oleh masyarakat luas, hingga saat ini masyarakat masih menggunakan tanaman obat untuk kesehatan (Yulianto, 2016).

WHO juga merencanakan gaya hidup sehat dengan kembali ke alam (back to nature). Anjurannya adalah untuk meningkatkan penggunaan makanan berserat tinggi dari tumbuhan tanpa pengawet, perasa, pewarna, pengembang, dan penambah aroma (Yulianto, 2016).

Desa Pringgabaya merupakan salah satu Desa yang berada di Kecamatan Pringgabaya Kabupaten Lombok Timur. Kawasan Desa Pringgabaya bisa dikatakan strategis. Kondisi alam yang dimiliki memungkinkan masyarakat sekitar untuk bercocok tanam dan menangkap ikan di laut, karena wilayah Desa Pringgabaya memiliki luas sekitar 224,326 $\mathrm{km} 2$ dan panjang lautan kurang lebih 27,38 km (Anonim, 2020). Masyarakat Desa Pringgabaya merupakan salah satu masyarakat di Indonesia yang masih menggunakan tanaman sebagai obat tradisional, mereka juga memiliki pengetahuan dalam pemanfaatan tanaman sebagai bahan baku obat tradisional dan dapat diterapkan dalam kehidupan sehari-hari.

Pengetahuan masyarakat Desa Pringgabaya tentang tanaman obat ini masih terpelihara karena merupakan tradisi secara turun temurun dari nenek moyang mereka. Pengetahuan, sikap, dan tindakan mengenai pemanfaatan tanaman tradisional yang tidak ternilai harganya ini belum dikaji dan diteliti secara mendalam atau maksimal. Pengetahuan tentang pemanfaatan tanaman obat hanya diwariskan secara lisan, sehingga kemungkinan lama kelamaan pengetahuan tersebut akan hilang atau resepnya menjadi tidak komplit. Hal inilah yang mendorong peneliti ingin melakukan penelitian tentang pemanfaatan tanaman sebagai obat tradisional di Desa Pringgabaya Kabupaten Lombok Timur.

Penelitian ini bertujuan untuk mengetahui tingkat pengetahuan, sikap, dan tindakan masyarakat dalam pemanfaatan tanaman sebagai obat tradisional di Desa Pringgabaya Kabupaten Lombok Timur.

\section{Metode}

Jenis penelitian yang digunakan adalah jenis penelitian deskriptif observasional kuantitatif dengan pendekatan cross sectional. Penelitian ini dilakukan di Desa Pringgabaya Kabupaten Lombok Timur, Provinsi Nusa Tenggara Barat yang di mulai pada bulan Juni 202I.

Populasi pada penelitian ini yaitu masyarakat yang berusia 20 sampai 60 tahun yang bertempat tinggal di Desa Pringgabaya Kecamatan Lombok Timur yang berjumlah 7.339 jiwa. Sedangkan sampel pada penelitian ini adalah sebagian dari populasi yang memenuhi kriteria inklusi, yaitu : masyarakat yang bertempat tinggal di Desa Pringgabaya Kabupaten Lombok Timur; berusia 20 sampai 60 tahun; sehat jasmani dan rohani; bersedia menjadi responden.

Dalam penelitian ini, teknik pengambilan sampel yang digunakan adalah Purposive Sampling. Instrumen pada penelitian ini menggunakan kuesioner. kuesioner yang dipilih sebagai alat 
penelitian telah diadaptasi dan dimodifikasi dari penelitian Siregar (2018) yaitu Gambaran Pengetahuan, Sikap, dan Tindakan Masyarakat Dalam Pemanfaatan Taman Obat Keluarga (TOGA) di Kelurahan Sioldengan Kecamatan Rantau Selatan.

Pada penelitian ini dilakukan uji validitas dan reliabilitas terlebih dahulu pada 35 responden dengan bantuan aplikasi SPSS versi 20 sehingga didapatkan pertanyaan yang valid dengan nilai $r$ hitung $>0,344$ dan alpha cronbach's yaitu 0,600.

Teknik analisis yang digunakan adalah analisis univariat (analisis deskriptif) dan data dapat disajikan dalam bentuk tabel distribusi frekuensi.

\section{Hasil dan Pembahasan}

Dari penelitian yang telah dilakukan dengan 379 responden yang memanfaatkan tanaman sebagai obat tradisonal didapatkan hasil :

Tabel I. Demografi Tingkat Pengetahuan Responden

\begin{tabular}{|c|c|c|c|c|c|}
\hline \multirow{2}{*}{\multicolumn{2}{|c|}{$\underset{i}{\text { Demograf }}$}} & \multicolumn{3}{|c|}{ Tingkat Pengetahuan } & \multirow[b]{2}{*}{ Total } \\
\hline & & $\begin{array}{c}\text { Baik } \\
\mathrm{n}(\%)\end{array}$ & $\begin{array}{c}\text { Cuku } \\
\mathrm{p} \\
\mathrm{n}(\%)\end{array}$ & $\begin{array}{c}\text { Kuran } \\
\mathrm{g} \\
\mathrm{n}(\%)\end{array}$ & \\
\hline \multirow{2}{*}{ JK } & $\mathrm{Lk}$ & $\begin{array}{c}\text { I I I } \\
(29,3 \\
)^{2}\end{array}$ & $\begin{array}{c}62 \\
(16,4)\end{array}$ & $\begin{array}{c}\text { I3 } \\
(3,4)\end{array}$ & $\begin{array}{c}\mathrm{I} 86 \\
(49,1 \% \\
)\end{array}$ \\
\hline & $\operatorname{Pr}$ & $\begin{array}{c}\text { II2 } \\
(39,3 \\
)^{2}\end{array}$ & $\begin{array}{c}74 \\
(19,5)\end{array}$ & $\begin{array}{c}7 \\
(\mathrm{I}, 8)\end{array}$ & $\begin{array}{c}193 \\
(50,9 \% \\
)\end{array}$ \\
\hline \multirow{2}{*}{ Usia } & $\mathrm{Lk}$ & $\begin{array}{c}149 \\
(39,3 \\
)\end{array}$ & $\begin{array}{c}\text { II0 } \\
(29,0)\end{array}$ & $\begin{array}{c}20 \\
(5,3)\end{array}$ & $\begin{array}{c}279 \\
(73,6 \% \\
)\end{array}$ \\
\hline & $\operatorname{Pr}$ & $\begin{array}{c}74 \\
(19,5 \\
)\end{array}$ & $\begin{array}{c}26 \\
(6,9)\end{array}$ & $\begin{array}{c}0 \\
(0,0)\end{array}$ & $\begin{array}{c}\text { I00 } \\
(50,9 \% \\
)\end{array}$ \\
\hline
\end{tabular}

Keterangan:

JK : Jenis Kelamin

Pr : Perempuan

Lk : Laki-laki

Pada tabel I di atas, dapat diketahui bahwa responden berjenis kelamin perempuan lebih banyak yaitu 193 responden (50,9\%) dibandingkan dengan laki-laki dengan jumlah 186 responden (49,I\%), hal ini berarti mayoritas responden berjenis kelamin perempuan. Hasil penelitian ini sejalan dengan penelitian yang dilakukan oleh Kristina, dkk (2007), yang menemukan bahwa gender penting dalam perilaku pengobatan sendiri. Wanita cenderung lebih mengetahui tentang pengobatan tradisional dibandingkan pria karena wanita lebih tertarik untuk memahami pengobatan secara lebih mendalam (Puspita, 2019).
Dari data penelitian di atas, dapat dijelaskan bahwa mayoritas responden berusia 20 - 40 tahun yaitu sebanyak 279 responden (73,6\%), sehingga hal ini menunjukkan bahwa kelompok usia responden masih termasuk dalam usia produktif. Hasil penelitian ini sejalan dengan pendapat Notoadmodjo (20I2), yang menyatakan bahwa faktor usia berpengaruh kuat terhadap pengetahuan manusia, dimana pada usia produktif daya tangkap dan pemikiran seseorang semakin berkembang sehingga memudahkan mereka untuk mengikuti berbagai kegiatan dan ada keinginan yang besar mempelajari informasi obat tradisional (Notoatmodjo, 2012).

Jumlah skor rata-rata seluruh pengetahuan responden tentang pemanfaatan tanaman obat adalah 7,60. Secara keseluruhan tingkat pengetahuan responden tentang pemanfaatan tanaman di Desa Pringgabaya Kabupaten Lombok Timur adalah $76,0 \%$, termasuk kategori pengetahuan baik.

Tabel 2. Distribusi Frekuensi Sikap Responden

\begin{tabular}{cccc}
\hline Variabel & Kategori & Frekuensi & $\begin{array}{c}\text { Persentase } \\
(\%)\end{array}$ \\
\hline \multirow{3}{*}{ Sikap } & Baik & 237 & 62,5 \\
& Cukup & I4I & 37,2 \\
& Kurang & I & 0,3 \\
\hline Total & & 379 & 100,0 \\
\hline
\end{tabular}

Berdasarkan tabel 2 di atas, dapat dijelaskan bahwa variabel sikap kategori baik berjumlah 237 responden (62,5\%), cukup baik berjumlah I4I responden $(37,2 \%)$, dan yang kurang baik berjumlah $\mathrm{I}$ responden $(0,3 \%)$.

Jumlah skor rata-rata seluruh sikap responden tentang pemanfaatan tanaman obat adalah 3I,79. Secara keseluruhan sikap responden tentang pemanfaatan tanaman sebagai obat tradisional di Desa Pringgabaya Kabupaten Lombok Timur adalah $79,5 \%$, termasuk kategori sikap baik. Hal ini dikarenakan sikap atau tanggapan masyarakat dalam pemanfaatan tanaman sebagai obat tradisional sudah tergolong baik.

Tabel 3. Distribusi Frekuensi Tindakan Responden

\begin{tabular}{cccc}
\hline Variabel & Kategori & Frekuensi & $\begin{array}{c}\text { Persentase } \\
\text { (\%) }\end{array}$ \\
\hline \multirow{3}{*}{ Tindakan } & Baik & I54 & 40,6 \\
& Cukup & I68 & 44,3 \\
& Kurang & 57 & 15,0 \\
\hline Total & & 379 & 100,0 \\
\hline
\end{tabular}

Berdasarkan tabel 3 di atas, dijelaskan variabel tindakan kategori baik berjumlah 154 responden (40,0\%), cukup baik berjumlah 168 responden (44,3\%), dan yang kurang baik berjumlah 57 responden $(\mathrm{I} 5,0 \%)$. Jumlah skor rata-rata seluruh 
tindakan responden tentang pemanfaatan tanaman obat adalah 6,57. Secara keseluruhan tindakan responden tentang pemanfaatan tanaman di Desa Pringgabaya Kabupaten Lombok Timur adalah $65,7 \%$, termasuk kategori tindakan cukup baik.

Ini disebabkan karena tidak semua masyarakat Desa Pringgabaya Kabupaten Lombok Timur yang menanam dan memanfaatan tanaman sebagai obat tradisional. Padahal cukup banyak masyarakat di Desa Pringgabaya Kabupaten Lombok Timur yang memiliki pekarangan rumah cukup memadai untuk menanam tanaman obat

\section{Simpulan dan Saran}

Berdasarkan hasil penelitian yang telah dilakukan tentang tingkat pengetahuan, sikap, dan tindakan masyarakat dalam pemanfaatan tanaman sebagai obat tradisional dapat ditarik kesimpulan bahwa tingkat pengetahuan masyarakat tentang pemanfaatan tanaman sebagai obat tradisional di Desa Pringgabaya Kabupaten Lombok Timur termasuk dalam kategori pengetahuan baik (76,0\%); sikap termasuk dalam kategori sikap baik (79,5\%); dan tindakan termasuk dalam kategori tindakan cukup baik (65,7\%).

Bagi peneliti selanjutnya diharapkan menambahkan variabel lain yang mempengaruhi tingkat pengetahuan responden, selain variabel yang digunakan untuk hasil yang lebih akurat, atau dapat menambahkan variabel yang berkaitan dengantingkat pendidikan dan pekerjaan. Dan untuk mencapai hasil yang baik, diperlukan penyuluhan tentang pemanfaatan tanaman sebagai obat tradisional.

\section{Daftar Pustaka}

Abdul, L. H. (20I4). Obat Tradisional. Jakarta: Buku Dokter EGC.

Alfi, I. (2019). Gambaran Penggunaan Obat Tradisional Sebagai Alternatif Pengobatan Pada Masyarakat Desa Pituruh Kecamatan Pituruh Kabupaten Purworejo Tahun 2019. Karya Tulis Ilmiah. Magelang: Universitas Muhammadiyah Magelang.

Anonim. (2013). Lampiran Peraturan Menteri Kesehatan Republik Indonesia Nomor 88 Tahun 2013 Tentang Rencana Induk Pengembangan Bahan Baku Obat Tradisional. Jakarta: Departemen Kesehatan RI.

Anonim. (2020). Profil Desa Pringgabaya. Lombok Timur: Kantor Kelurahan Desa Pringgabaya.

Arief, H. (2013). 262 Tumbuhan Obat dan Khasiatnya. Jakarta: Penebar Swadaya.

Astutik, A. W. (2020). Pengetahuan, Sikap, Dan Perilaku Penggunaan Obat Pada Kalangan
Mahasiswa Jember. Jember: Universitas Jember.

Bustanussalam. (2016). Pemanfaatan Obat Tradisional (Herbal) Sebagai Obat Alternatif. Biotrends.

Jabbar, A., Musdalipah, \& Nurwati, A. (2016). Studi Pengetahuan, Sikap, dan Tindakan Terhadap Penggunaan Obat Tradisional Bagi Masyarakat di Desa Sabi-Sbila Kecamatan Mowewe Kabupaten Kolaka Timur. Majalah Farmasi, Sains, dan Kesehatan, 19-22.

Lestari, P. (2016). Studi Tanaman Khas Sumatera Utara Yang Berkhasiat Obat. Jurnal Farmanesia, I I-2I.

Merdekawati, R. B. (2016). Gambaran Dan Tingkat Pengetahuan Penggunaan Obat Tradisional Sebagai Alternatif Pengobatan Pada Masyarakat $R W 005$ Desa Sindurjan, Kecamatan Purwerejo, Kabupaten Purworejo. Yogyakarta: Universitas Muhammadiyah Yogyakarta.

Notoatmodjo, S. (2012). Promosi Kesehatan dan Perilaku Kesehatan. Jakarta: Rineka Cipta.

Pangesti, A. (2012). Gambaran Tingkat Pengetahuan Dan Aplikasi Kesiapsiagaan Bencana Pada Mahasiswa Fakultas Ilmu Keperawatan Universitas Indonesia Tahun 2012. Jakarta: Universitas Indonesia.

Puspita, A. N. (2019). Gambaran Pengetahuan Dan Sikap Masyarakat Terhadap Penggunaan Obat Tradisional Di Kecamatan Mlati. Skripsi. Yogyakarta: Universitas Islam Indonesia.

Siregar, R. P. (2018). Gambaran Pengetahuan, Sikap Dan Tindakan Masyarakat Dalam Pemanfaatan Taman Obat Keluarga (TOGA) Di Kelurahan Sioldengan Kecamatan Rantau Selatan. Skripsi. Medan: Politeknik Kesehatan Kemenkes Medan.

Suwaryo, P. A., \& Yuwono, P. (2017). FaktorFaktor Yang Mempengaruhi Tingkat Pengetahuan Masyarakat Dalam Mitigasi Bencana Alam Tanah Longsor. Unimma, 305-3I4.

Vera, Y., \& Yanti, S. (2020). Penyuluhan Pemanfaatan Tanaman Obat Dan Obat Tradisional Indonesia Untuk Pencegahan Dan Penanggulangan Penyakit Hipertensi Di Desa Salam Bue. Education and Development , II-I4.

Veriana, T. (2014). Studi Etnobotasi Tumbuhan Obat Tradisional Oleh Suku Jawa Dan Lembak Kelingi Di Kecamatan Sindang Kelingi Kabupaten Rejang Lebong Dan 
Implementasinya Pada Pembelajaran Biologi $S M A$. Bengkulu: Universitas Bengkulu Press.

Wahyuni, L., Olde, \& Sofyan. (2018). Pengetahuan Dan Sikap Masyarakat Desa Binaan Stikes Muhammadiyah Sidrap Tentang Penggunaan Obat Herbal. Jurnal Ilmiah Kesehatan Iqra, Volume 6, No I, 48-5I.

Yulianto, S. (2016). Pengetahuan Masyarakat Tentang Taman Obat Keluarga Di Nglinggi, Klaten Selatan. Kebidanan Dan Kesehatan Tradisional, Volume I, No 2, I00-I44. 